\title{
YAC Cloning
}

National Cancer Institute

\section{Source}

National Cancer Institute. YAC Cloning. NCI Thesaurus. Code C19655.

Yeast artificial chromosomes or YAC is a vector system for cloning genomic DNA for genomic map construction and can carry from 100 to $>2000 \mathrm{~kb}$ of foreign DNA. 